\title{
STUDI TENTANG KOMPONEN PEMBELAJARAN GEOGRAFI SMA/MA ANTARA WILAYAH PERKOTAAN DAN PERDESAAN DI KABUPATEN BULELENG SERTA IMPLIKASINYA TERHADAP HASIL BELAJAR SISWA
}

\author{
Nyoman Sri Artini ${ }^{1}$, Ida Bagus Made Astawa ${ }^{*}$ \\ Prodi Pendidikan Geografi,Universitas Pendidikan Ganesha, Indonesia
}

\author{
A R T I C L E I N F O \\ Article history: \\ Received 13Januari 2019 \\ Received in revised form \\ 6 Februari 2019 \\ Accepted 12 Februari 2019 \\ Available online 31 Maret \\ 2019

\section{Kata Kunci:} \\ komponen pembelajaran \\ geografi, hasil belajar, \\ perdesaan, perkotaan \\ Keywords: \\ geography learning \\ component; rural areas; \\ urban areas
}

\begin{abstract}
A B S T R A K
Penelitian ini dilaksanakan pada SMA/MA di Kabupaten Buleleng dengan tujuan: (1) mengidentifikasi sebaran komponen pembelajaran geografi SMA/MA di wilayah perkotaan dan perdesaan Kabupaten Buleleng, (2) mengidentifikasi hasil belajar geografi siswa SMA/MA di wilayah perkotaan dan perdesaan, (3) menganalisis hubungan ketersediaan komponen pembelajaran geografi dengan hasil belajar geografi siswa SMA/MA di wilayah perkotaan dan perdesaan Kabupaten Buleleng. Rancangan penelitian menggunakan rancangan deskriptif. Populasi dalam penelitian ini mencakup seluruh SMA/MA di Kabupaten Buleleng yang memiliki nilai ujian nasional geografi tahun pelajaran 2016/2017. Data dikumpulkan menggunakan metode pencatatan dokumen yang dilengkapi dengan metode observasi dan dokumentasi yang selanjutnya dianalisis secara deskriptif kualitatif. Hasil penelitian menunjukkan: 1) Terdapat perbedaan komponenkomponen pembelajaran geografi yang dimiliki SMA/MA antara wilayah
\end{abstract} perkotaan dan perdesaan di Kabupaten Buleleng. 2) Rata-rata hasil belajar geografi siswa SMA/MA di wilayah perdesaan dan perkotaan Kabupeten Buleleng terkategori kurang. 3) Kulifikasi guru geografi tidak menunjukkan hubungan yang jelas dengan hasil belajar geografi siswa.

\section{A B S T R A C T}

The research was conducted in the high school students District of Buleleng with the aims of: (1) identify the deployment of geography learning components for some high schools in the urban and the rural District of Buleleng, (2) identify the learning outcomes of geography subjects for the high school students, (3) analyze how is the relationship of the availability of geographic learning component for high school students' learning outcomes in urban and rural areas District of Buleleng. The study design used the descriptive design. The populations of this research were high schools in the District of Buleleng which use geography subject as their consideration for national examination score in the academic year of 2016/2017. Data were collected by closed interview, observation, documentation, and record-keeping analyzed by qualitative descriptive. The results have shown: (1) there are differences in the geography learning components owned high school students in the urban and rural regions District Buleleng. 2) Average geography student learning outcomes high school students in rural areas and urban District Buleleng categorized less. 3) Qualifications of geography teacher did not show a clear relationship with geography student learning outcomes.

\section{Pendahuluan}


Badan Pusat Statistik (2010) mengklasifikasikan wilayah Indonesia berdasarkan karakteristik wilayahnya menjadi dua, yaitu perkotaan dan perdesaan. Secara keruangan fenomena-fenomena bentang alam yang ada di perdesaan dan perkotaan berbeda. Di perkotaan lebih banyak fenomena bentang alam buatan, sedangkan di perdesaan lebih banyak bentang alam alami yang secara umum adalah bidang pertanian. Hal tersebut menyebabkan perbedaanperbedaan dalam berbagai hal, seperti fasilitas atau tingkat pembangunan, akses pendidikan, dan ketersediaan sarana prasarana pendidikan.

Kesenjangan pendidikan yang terdapat antara perdesaan dan perkotaan tidak hanya dalam akses menuju sekolahnya saja, tetapi masih banyak aspek-aspek kesenjangan pendidikan lainnya, seperti kesenjangan sarana dan prasarana sekolah (Vito, Krisnani, \& Resnawati, 2015). Infrastruktur pendidikan seperti fasilitas-fasilitas sekolah sangat buruk yang tidak layak untuk dijadikan sarana penunjang pendidikan terutama di perdesaan, buku-buku pelajaran yang sudah rusak, dan dana bantuan operasional sekolah (BOS) yang belum efektif bagi semua kalangan menjadi permasalahan pendidikan saat ini (Anas, Riana, \& Apsari, 2015).

Terwujudnya tujuan pendidikan nasional harus didukung oleh berbagai faktor. Sumarmi dalam (Widyastuti ddk, 2017) mengemukakan, terdapat tiga faktor yang sangat berpengaruh terhadap keberhasilan pendidikan, yaitu: 1) perangkat keras (hardware), yang meliputi ruang belajar, peralatan praktik, laboratorium, dan perpustakaan; 2) perangkat lunak (software), yang meliputi kurikulum, program pembelajaran, manajemen sekolah, sistem pembelajaran; 3) perangkat piker (brainware), yaitu guru, kepala sekolah, peserta didik, dan orang-orang yang terkait dalam proses tersebut.

Tujuan pendidikan dapat dicapai dengan adanya sebuah program yang terencana. Program itu adalah kurikulum sebagai pedoman penunjang tercapainya tujuan tersebut. Akan tetapi sebuah program yang terencana tidak akan berhasil tanpa adanya sebuah pelaksanaan yang disebut pembelajaran. Pembelajaran sebagai bagian dari pendidikan merupakan suatu bentuk implementasi proses interaksi antara guru dengan siswa guna tercapainya tujuan pendidikan.

Pembelajaran geografi dianggap membosankan dan tidak menarik bagi siswa. Terdapat sejumlah faktor yang menjadi penyebab, yaitu: (1) pelajaran geografi sering terjebak pada aspek kognitif tingkat rendah yaitu menghapal nama-nama tempat, sungai dan gunung, atau sejumlah fakta lainnya; (2) ilmu geografi sering dikaitkan ilmu yang hanya pembuatan peta; (3) geografi hanya menggambarkan tentang perjalanan-perjalanan manusia di permukaan bumi; (4) proses pembelajaran ilmu geografi cenderung bersifat verbal, kurang melibatkan fakta-fakta aktual, tidak menggunakan media kongkret dan teknologi mutakhir; (5) kurang aplikabel dalam memecahkan masalah-masalah yang berkembang saat ini (Maryani, 2006).

Berdasarkan fenomena tersebut, pembelajaran geografi secara substansi membutuhkan suatu proses atau penyesuaian agar siswa menjadi tertarik terhadap pembelajarannya. Namun demikian, yang bisa segera ditindaklanjuti adalah yang bersifat teknis. Hal yang bersifat teknis dalam hal ini mencakup gurunya, peserta didik, dan sarana-prasarana. Ketiga komponen, secara teknis dalam pembelajaran geografi harus dapat terpenuhi ketersediaannya guna menghasilkan lulusan yang berkualitas. Ketiga komponen pembelajaran geografi tersebut setiap wilayah ketersediaannya pun berbeda. Komponen pembelajaran tersebut cenderung lebih memadai di wilayah perkotaan dari pada di wilayah perdesaan. Hal tersebut akan berdampak terhadap hasil belajar dari masing-masing sekolah, baik di perdesaan maupun di perkotaan.

Fenomena tersebut juga terdapat di Kabupaten Buleleng. Berdasarkan hasil ujian akhir siswa di masing-masing sekolah, nilai mata pelajaran geografi pada tahun 2014 dan 2015 lebih rendah dibandingkan dengan mata pelajaran lainnya (Kementerian Pendidikan dan Kebudayaan 
Indonesia, 2015). Dalam hal ini dapat diidentifikasi bahwa permasalahan tersebut dapat berasal dari dalam maupun dari luar proses pembelajaran yang menyebabkan rendahnya nilai ujian para siswa pada mata pelajaran geografi.

Berdasarkan latar belakang di atas, maka adapun rumusan masalah dalam penelitian ini adalah (1) bagaimana sebaran komponen pembelajaran geografi SMA/MA di wilayah perkotaan dan perdesaan Kabupaten Buleleng?, (2) bagaimana hasil belajar geografi siswa SMA/MA di wilayah perkotaan dan perdesaan Kabupaten Buleleng?, (3) bagaimana hubungan ketersediaan komponen pembelajaran geografi dengan hasil belajar geografi siswa SMA/MA di wilayah perkotaan dan perdesaan Kabupaten Buleleng?. Sesuai dengan rumusan masalah yang dirumuskan maka tujuan dalam penelitian ini yaitu untuk (1) mengidentifikasi sebaran komponen pembelajaran geografi SMA/MA wilayah perkotaan dan perdesaan di Kabupaten Buleleng, (2) mengidentifikasi hasil belajar geografi siswa SMA/MA di wilayah perkotaan dan perdesaan Kabupaten Buleleng, (3) menganalisis hubungan ketersediaan komponen pembelajaran geografi dengan hasil belajar geografi siswa SMA/MA di wilayah perkotaan dan perdesaan Kabupaten Buleleng.

\section{Metode}

Penelitian ini dirancang sebagai penelitian deskriptif, karena gejala-gejala yang diteliti dalam penelitian sudah ada secara wajar tanpa dibuat oleh peneliti. Data yang dibutuhkan dalam penelitian ini adalah sekunder meliputi data guru geografi, ketersediaan sarana dan prasarana pembelajaran geografi, jumlah peserta didik IPS tahun pelajaran 2016/2017, nilai akhir ujian nasional siswa tahun pelajaran 2016/2017, waktu pendirian SMA/MA di Kabupaten Buleleng. Metode pengumpulan data yang digunakan yakni metode wawancara, observasi, pencatatan dokumen, dan dokumentasi. Rumusan masalah pertama menggunakan metode deskriptif kualitatif dengan teknik analisis berpendekatan spasial yang divisualisasikan melalui peta sebaran ketersedian komponen pembelajaran geografi SMA/MA di wilayah perkotaan dan perdesaan Kabupaten Buleleng. 2) Rumusan masalah kedua menggunakan metode deskriptif kualitatif dengan mengkategorikan nilai ujian nasional siswa berdasarkan ketentuan dari Badan Standar Nasional Pendidikan. 3) Rumusan masalah ketiga menggunakan metode analisis deskriptif kualitatif dengan tabel silang guna mengetahui hubungan komponen pembelajaran geografi dengan hasil belajar geografi siswa masing-masing SMA/MA di wilayah perkotaan dan perdesaan Kabupaten Buleleng.

\section{Hasil dan pembahasan}

\subsection{Sebaran Komponen Pembelajaran Geografi SMA/MA di Wilayah Perkotaan dan Perdesaan Kabupaten Buleleng}

Distribusi komponen pembelajaran geografi adalah sebaran ketersediaan kelengkapan pembelajaran geografi. Komponen pembelajaran geografi meliputi sarana prasarana, guru, dan siswa (peserta didik). Hasil penelitian mengidentifikasi jenis komponen-komponen pembelajaran geografi di Kabupaten Buleleng di wilayah perkotaan dan perdesaan dapat dijabarkan sebagai berikut. 


\section{Kualifikasi Guru Mata Pelajaran Geografi SMA/MA di Kabupaten Buleleng}

Guru adalah komponen utama dalam suatu pembelajaran. Hasil penelitian menunjukkan bahwa kualifikasi guru mata pelajaran geografi di Kabupaten Buleleng bervariasi.

\section{Tabel 1}

Kualifikasi Guru Mata Pelajaran Geografi SMA/MA di Kabupaten Buleleng yang Memiliki Nilai Ujian Nasional Geografi tahun pelajaran 2016/2017

\begin{tabular}{|c|c|c|c|c|c|c|c|}
\hline \multirow{2}{*}{ No } & \multirow{2}{*}{ Kualifikasi } & \multicolumn{2}{|c|}{ Perdesaan } & \multicolumn{2}{|c|}{ Perkotaan } & \multicolumn{2}{|c|}{ Jumlah } \\
\hline & & Negeri & Swasta & Negeri & Swasta & $\mathbf{N}$ & $\%$ \\
\hline (1) & (2) & (3) & (4) & (5) & (6) & (7) & $(8)$ \\
\hline 1 & $\begin{array}{l}\text { S1 Geografi Tersertifikasi/S2 } \\
\text { Pendidikan Geografi }\end{array}$ & 2 & - & 9 & 10 & 21 & 60,0 \\
\hline 2 & $\begin{array}{l}\text { S1Pendidikan Geografi/S2 } \\
\text { Non Pendidikan Geografi }\end{array}$ & - & - & 1 & 1 & 2 & 5,7 \\
\hline 3 & S1 Geografi & - & 1 & 2 & 6 & 9 & 25,7 \\
\hline 4 & S1 Non Geografi & - & 2 & - & - & 2 & 5,7 \\
\hline 5 & SMA & - & 1 & - & - & 1 & 2,9 \\
\hline & Jumlah & 2 & 4 & 12 & 17 & 35 & 100 \\
\hline & Persentase (\%) & 5.7 & 11.4 & 34.3 & 48.6 & & 100 \\
\hline
\end{tabular}

Tabel 1 menunjukkan bahwa guru-guru geografi di Kabupaten Buleleng sebagain besar sudah tersertifikasi dan sudah menamatkan pendidikan di jenjang S-1. Pada SMA/MA swasta di perdesaan sebagian besar guru geografinya belum tersertifikasi. Namun demikian, pada SMA/MA di perkotaan juga masih terdapat guru geografi yang belum tersertifikasi.

\section{Jumlah Siswa IPS SMA/MA Tahun Pelajaran 2016/2017 di Kabupaten Buleleng menurut Wilayah Perkotaan dan Perdesaan}

Besar kecilnya jumlah siswa dalam satu rombongan belajar sangat berpengaruh terhadap efektifitas suatu pembelajaran. Hasil penelitian menunjukkan bahwa jumlah siswa IPS tahun pelajaran 2016/2017 pada SMA/MA di Kabupaten Buleleng bervariasi antara wilayah perkotaan dan perdesaan.

Tabel 2

Jumlah Siswa IPS SMA/MA Tahun Pelajaran 2016/2017 di Kabupaten Buleleng menurut Wilayah Perkotaan dan Perdesaan

\begin{tabular}{ccccccc}
\hline NO & Wilayah & Status & SMA/MA & Siswa & Mean & \% \\
\hline$(1)$ & $(2)$ & $(3)$ & $(4)$ & $(5)$ & $(8)$ & $(7)$ \\
\hline \multirow{2}{*}{1} & Perdesaan & Negeri & 2 & 118 & 59 & 63.4 \\
\cline { 3 - 7 } & Swasta & 3 & 103 & 34 & 36.6 \\
\hline \multirow{2}{*}{2} & Jumlah di perdesan & $\mathbf{5}$ & $\mathbf{2 2 1}$ & $\mathbf{9 3}$ & $\mathbf{4 8 . 4}$ \\
\hline & Perkotaan & Negeri & 8 & 557 & 70 & 70.7 \\
\cline { 3 - 7 } & Swasta & 12 & 342 & 29 & 29.3 \\
\hline & Jumlah di perkotaan & $\mathbf{2 0}$ & $\mathbf{8 9 9}$ & $\mathbf{9 9}$ & $\mathbf{5 1 . 6}$ \\
\hline & Jumlah & $\mathbf{2 5}$ & $\mathbf{1 . 1 2 0}$ & $\mathbf{1 9 2}$ & $\mathbf{1 0 0}$
\end{tabular}

Tabel 2 menunjukkan bahwa jumlah peserta didik IPS SMA/MA tahun pelajaran 2016/2017 di Kabupaten Buleleng lebih banyak terdapat di perkotaan dibandingkan di perdesaan. Pada wilayah perdesaan jumlah peserta didik IPS lebih banyak terdapat pada SMA/MA dengan status negeri. Demikian juga dengan wilayah perkotaan lebih banyak terdapat peserta didik pada SMA/MA dengan status negeri. 


\section{Sarana dan Prasarana Pembelajaran geografi}

Sarana dan prasarana pembelajaran geografi adalah fasilitas penunjang dalam proses belajar mengajar.

\section{Tabel 3}

Rata-Rata Ketersediaan Sarana dan Prasarana Pembelajaran Geografi SMA/MA di Wilayah Perkotaan dan Perdesaan Kabupaten Buleleng yang Memiliki Nilai Ujian Nasional Geografi Tahun Pelajaran 2016/2017

\begin{tabular}{|c|c|c|c|c|c|c|}
\hline No & Wilayah & Status & SMA/MA & Sarana Prasarana & Mean & $\%$ \\
\hline (1) & $(2)$ & (3) & (4) & (5) & (7) & (6) \\
\hline \multirow[t]{2}{*}{1} & \multirow[t]{2}{*}{ Perdesaan } & Negeri & 2 & 23 & 11.5 & 56 \\
\hline & & Swasta & 3 & 27 & 9 & 44 \\
\hline \multicolumn{3}{|c|}{ Jumlah di Perdesaan } & 5 & 50 & 10 & 51 \\
\hline \multirow[t]{2}{*}{2} & \multirow[t]{2}{*}{ Perkotaan } & Negeri & 8 & 81 & 10.1 & 52 \\
\hline & & Swasta & 12 & 110 & 9.2 & 48 \\
\hline \multicolumn{3}{|c|}{ Jumlah di Perkotaan } & 20 & 191 & 9,6 & 49 \\
\hline \multicolumn{3}{|c|}{ Jumlah } & 25 & 241 & 39.8 & 100 \\
\hline
\end{tabular}

Tabel 3 menunjukkkan bahwa rata-rata ketersediaan sarana dan prasarana pembelajaran geografi SMA/MA di wilayah perkotaan dan perdesaan Kabupaten Buleleng yang memiliki nilai ujian nasional geografi tahun pelajaran 2016/2017 adalah bervariasi. Rata-rata jumlah jenis sarana prasarana pembelajaran geografi yang dimiliki ketersediannya lebih besar di perdesaan dibandingkan dengan di perkotaan. Hal tersebut dipengaruhi oleh keberadaan sekolah swasta dengan rata-rata ketersediaan sarana prasarana yang lebih rendah dibandingkan SMA/MA negeri. Berarti ketersediaan sarana prasarana untuk pembelajaran geografi pada SMA/MA di kabupaten Buleleng lebih komplit di sekolah negeri dibandingkan swasta.

\section{Hasil Belajar Geografi Siswa SMA/MA di Wilayah Perkotaan dan Perdesaan Kabupaten Buleleng}

Hasil belajar siswa pada mata pelajaran geografi yang dimaksud adalah nilai yang diperoleh siswa dari hasil ujian nasional tahun pelajaran 2016/2017. Ujian nasional merupakan evaluasi yang dilakaukan secara serentak di seluruh wilayah Indonesia. Walaupun tidak lagi digunakan sebagai penentu satu-satunya kelulusan siswa. Tabel 4 menunjukkan nilai rata-rata ujian nasional mata pelajaran geografi SMA/MA berdasarkan wilayah dan status sekolah di Kabupaten Buleleng

\section{Tabel 4}

Nilai Rata-rata Sekolah Hasil Ujian Nasional Geografi Tahun Pelajaran 2016/2017 di Wilayah Perdesaan dan Perkotaan Kabupaten Buleleng

\begin{tabular}{|c|c|c|c|c|c|}
\hline NO & Wilayah & Status & SMA/MA & Rata-rata UN & Kategori \\
\hline (1) & $(2)$ & (3) & (4) & (5) & (6) \\
\hline \multirow[t]{2}{*}{1} & \multirow[t]{2}{*}{ Perdesaan } & Negeri & 2 & 43.63 & Kurang \\
\hline & & Swasta & 3 & 45.95 & Kurang \\
\hline \multicolumn{3}{|c|}{ Perdesaan } & 5 & 45.02 & Kurang \\
\hline \multirow[t]{4}{*}{2} & Perkotaan & Negeri & 8 & 54.01 & Kurang \\
\hline & & Swasta & 12 & 43.09 & Kurang \\
\hline & \multicolumn{2}{|l|}{ Perkotaan } & 20 & 47.46 & Kurang \\
\hline & \multicolumn{2}{|l|}{ Jumlah } & 25 & & \\
\hline
\end{tabular}


Tabel 4 menunjukkan bahwa terdapat perbedaan nilai rata-rata ujian nasional geografi SMA/MA tahun pelajaran 2016/2017 di Kabupaten Buleleng antara wilayah perkotaan dan perdesaan. Nilai rata-rata ujian nasional geografi SMA/MA tahun 2016/2017 lebih tinggi di wilayah perkotaan dari pada di perdesaan. Namun demikian, berdasarkan kategori yang ditetapkan oleh Badan Standar Nasional Pendidikan (BSNP) nilai rata-rata ujian nasional pada mata pelajaran geografi di kabupaten Buleleng tergolong "kurang" (nilai 0 - 55), baik di wilayah perkotaan maupun perdesaan.

\subsection{Ketersediaan Komponen Pembelajaran Geografi SMA/MA dan Hasil Belajar Geografi Siswa di Wilayah Perkotaan dan Perdesaan Kabupaten Buleleng}

Hubungan antara ketersediaan komponen pembelajaran geografi SMA/MA dengan hasil belajar geografi siswa di wilayah perkotaan dan perdesaan Kabupaten Buleleng dianalisis dengan menggunakan tabel silang yang dilakukan untuk masing-masing komponen.

\section{Hubungan Antara Kualifikasi Guru dan Hasil Belajar}

Hasil penelitian menunjukkan bahwa kualifikasi guru yang mengajar mata pelajaran geografi pada SMA/MA di Kabupaten Buleleng tidak berhubungan dengan hasil belajar siswa.

Tabel 5

Hubungan Kualifikasi Guru Geografi terhadap Hasil Belajar Geografi Siswa SMA/MA di Wilayah Perkotaan dan Perdesaan Kabupaten Buleleng

\begin{tabular}{clccc}
\hline \multirow{2}{*}{ No } & \multicolumn{1}{c}{ Kualifikasi Guru } & \multicolumn{2}{c}{ Rata-rata Hasil Belajar } & \multicolumn{2}{c}{$\begin{array}{c}\text { Rata-Rata } \\
\text { Total }\end{array}$} \\
\cline { 3 - 5 }$(1)$ & \multicolumn{1}{c}{$(2)$} & Perdesaan & Perkotaan & $(4)$ \\
\hline 1 & $\begin{array}{l}\text { S1 Pendidikan Geografi Tersertifikasi/S2 } \\
\text { Pendidikan Geografi }\end{array}$ & 43.60 & 46,00 & 44.80 \\
\hline 2 & $\begin{array}{l}\text { S1 Pendidikan Geografi/ S2 Non } \\
\text { Pendidikan Geografi }\end{array}$ & - & 73.50 & \multirow{2}{*}{73.50} \\
\hline 3 & S1 Pendidikan Geografi & 48.25 & 46.32 & 47.285 \\
\hline 4 & S1 Non Pendidikan Geografi & 49.05 & - & 49.05 \\
\hline 5 & SMA & 40.55 & - & 40.55 \\
\hline & & Sumber: Analisis data sekunder & &
\end{tabular}

Tabel 5 menunjukkan bahwa rata-rata hasil belajar siswa tertinggi untuk mata pelajaran geografi diperoleh dari guru geografi yang berkualifikasi S1 Pendidikan Geografi dengan S2 Nonpendidikan Geografi. Rata-rata hasil belajar geografi siswa yang diajarkan oleh guru-guru geografi yang berkualifikasi nonpendidikan geografi dan SMA ternyata lebih rendah dibandingkan dengan guru dengan kualifikasi lainnya. Hasil belajar yang ditunjukkan dari guruguru yang berkualifikasi S1 Pendidika Geografi/S2 Pendidikan Geografi yang lebih rendah dibandingkan yang dihasilkan oleh guru-guru yang berkualifikasi S1 Pendidikian Geografi S2 Non Pendidikan Geografi, demikian juga dengan guru yang hanya berkualifikasi S1 Pendidikan Geografi yang belum tersertifikasi.

\section{Hubungan Antara Jumlah Siswa dan Hasil Belajar}

Jumlah siswa berhubungan negatif terhadap hasil belajar. Hasil penelitian menunjukkan bahwa hubungan tersebut dengan jelas terlihat di Kabupaten Buleleng. 
Tabel 6

Hubungan Jumlah Siswa terhadap Hasil Belajar Geografi Siswa SMA/MA di Wilayah Perkotaan dan Perdesaan Kabupaten Buleleng

\begin{tabular}{|c|c|c|c|c|c|}
\hline \multirow{2}{*}{ No } & \multirow{2}{*}{$\begin{array}{c}\text { Status } \\
\text { Sekolah }\end{array}$} & \multirow{2}{*}{$\begin{array}{c}\text { Jumlah } \\
\text { Siswa }\end{array}$} & \multicolumn{2}{|c|}{ Rata-rata Hasil Belajar } & \multirow{2}{*}{$\begin{array}{c}\text { Rata-rata } \\
\text { Total }\end{array}$} \\
\hline & & & Perdesaan & Perkotaan & \\
\hline$(1)$ & $(2)$ & (3) & (4) & (5) & $(6)$ \\
\hline \multirow{3}{*}{1} & \multirow{3}{*}{ Negeri } & $<20$ & - & 73.6 & 73.6 \\
\hline & & $20-36$ & 43.6 & 51.2 & 47.4 \\
\hline & & $>36$ & - & - & - \\
\hline \multirow{6}{*}{2} & \multirow{3}{*}{ Swasta } & $<20$ & - & 45.2 & 45.2 \\
\hline & & $20-36$ & 46.0 & 43.7 & 44.85 \\
\hline & & $>36$ & - & - & - \\
\hline & \multirow{3}{*}{ Total } & $<20$ & - & 47.50 & 47.50 \\
\hline & & $20-36$ & 45.02 & 47.44 & 46.23 \\
\hline & & $>36$ & - & - & - \\
\hline
\end{tabular}

Tabel 6 menunjukkan hasil belajar geografi siswa SMA/MA lebih tinggi pada rombongan belajar yang jumlah siswanya lebih sedikit. Di Kabupaten Buleleng rata-rata jumlah siswa dalam satu rombongan belajar tidak lebih dari jumlah kelas ideal yakni 20 sampai 36 siswa. baik di wilayah perkotaan maupun perdesaan. Selain itu, jika dilihat dari status sekolah, konsistensi semakin sedikit siswa hasil belajar semain tinggi juga terlihat. Hal tersebut menunjukkan bahwa ada hubungan antara jumlah siswa dan hasil belajar. Semakin sedikit jumlah siswanya, hasil belajar geografi semakin tinggi.

\section{Hubungan Antara Sarana Prasarana dan Hasil Belajar}

Sarana prasarana dalam suatu mempelajaran merupakan hal yang penting untuk menunjang terselenggaranya suatu proses pembelajaran yang baik dan bermakna. Hasil penelitian menunjukkan sarana prasarana pembelajaran geografi pada SMA/MA di Kabupaten Buleleng dapat diklasifikasi menjadi tiga (3), yaitu tinggi, sedang, dan kurang. SMA/MA dengan sarana prasaran tinggi ketersediaanya mencakup 13 - 17 jenis sarana prasarana, SMA/MA dengan sarana prasaran cukup ketersediaanya mencakup ketersediaan $8-12$ jenis sarana prasarana, SMA/MA dengan sarana prasaran kurang ketersediaanya mencakup $3-7$ jenis sarana prasarana.

Di perkotaan, sarana prasarana pembelajaran geografi menunjukkan hubungan yang positif dengan hasil belajar geografi siswa. Semakin tinggi kriteria ketersediaan sarana prasarana, semakin tinggi pula hasil belajarnya. Namun hal tersebut tidak terlihat di perdesaan.

Tabel 7

Hubungan Sarana Prasarana terhadap Hasil Belajar Geografi Siswa SMA/MA di Wilayah Perkotaan dan Perdesaan Kabupaten Buleleng

\begin{tabular}{|c|c|c|c|c|}
\hline \multirow{2}{*}{ No } & \multirow{2}{*}{ Sarana Prasarana } & \multicolumn{2}{|c|}{ Rata-rata Hasil Belajar } & \multirow{2}{*}{ Total } \\
\hline & & Perdesaan & Perkotaan & \\
\hline$(1)$ & $(2)$ & (3) & (4) & (5) \\
\hline 1 & Tinggi & 43.47 & 57.63 & 50.55 \\
\hline 2 & Cukup & 45.41 & 47.22 & 46.32 \\
\hline 3 & Kurang & - & 41.84 & 41.84 \\
\hline
\end{tabular}

Tabel 7 menunjukkan nilai rata-rata hasil belajar geografi secara keseluruhan lebih tinggi pada SMA/MA yang memiliki sarana prasarana yang terkategori tinggi dari pada kategori cukup maupun kurang. Namun hal tersebut hanya terjadi di wilayah perkotaan Kabupaten Buleleng. Di 
wilayah perdesaan Kabupaten Buleleng, hubungan antara sarana prasara dengan hasil belajar menjadi tidak jelas. Di wilayah perdesaan Kabupaten Buleleng, rata-rata hasil belajar geografi siswa pada SMA/MA dengan sarana prasarana yang tinggi ternyata lebih rendah dibandingkan dengan SMA/MA dengan sarana prasarana cukup.

\section{Simpulan dan saran}

Berpijak pada hasil temuan dalam pembahasan yang telah dilakukan, dapat disimpulkan tiga hal sesuai dengan rumusan masalah yang telah dikemukakan. Simpulan tersebut dapat dikemukakan sebagai berikut. 1)Terdapat perbedaan komponen-komponen pembelajaran geografi yang dimiliki SMA/MA antara wilayah perkotaan dan perdesaan di Kabupaten Buleleng. Komponen-komponen pembelajaran geografi pada SMA/MA di wilayah perkotaan Kabupaten Buleleng lebih tinggi dibandingkan dengan wilayah perdesaan. 2) Rata-rata hasil belajar geografi siswa SMA/MA di wilayah perdesaan dan perkotaan Kabupeten Buleleng terkategori kurang. Dari jumlah SMA/MA yang terdapat di Kabupaten Buleleng, hanya 8\% yang tergolong baik ratarata hasil belajarnya, 92\% terkategori kurang. Terdapat perbedaan rata-rata nilai hasil belajar geografi siswa antara wilayah perkotaan dan perdesaan di Kabupaten Buleleng. 3) Komponen pembelajaran geografi SMA/MA di Kabupaten Buleleng tidak selalu memiliki hubungan yang jelas dengan hasil belajar geografi siswa, baik di perdesaan maupun di perkotaan. Kulifikasi guru geografi tidak menunjukkan hubungan yang jelas dengan hasil belajar geografi siswa. Berbeda halnya dengan jumlah siswa dan sarana prasarana. Kedua komponen pembelajaran geografi ini memiliki hubungan yang jelas dengan hasil belajar geografi siswa di Kabupaten Buleleng, baik di perkotaan maupun di perdesaan. Jumlah siswa berpengaruh negatif terhadap hasil belajar siswa baik di perdesaan maupun di perkotaan. Sementara, sarana prasarana berpengaruh positif terhadap hasil belajar geografi siswa, baik di perkotaan maupun di perdesaan Kabupaten Buleleng.

Berdasarkan hasil penelitian yang telah dilakukan, dapat dikemukakan saran-saran sebagai berikut.1) Guru disarankan untuk lebih meningkatkan kompetensi pedagogiknya, karena kompetensi professional saja tidak menyebabkan hasil belajar siswa menjadi lebih baik. 2) Disarankan kepada pihak sekolah untuk bisa meningkatkan kualitas sekolah melalui pemanfaatan dana BOS untuk keperluan pemenuhan sarana dan prasarana penunjang pembelajaran geografi. 3) Disarankan kepada dinas pendidikan bisa mengawasi perkembangan sekolah baik di perdesaan maupun diperkotaan, dan mendistribusikan dana BOS secara proporsional kepada sekolah-sekolah yang benar-benar memerlukan.

\section{Ucapan terimakasih}

Penelitian ini dapat diselesaikan berkat bimbingan dan dukungan dari berbagai pihak. Pada kesempatan ini ucapan terima kasih disampaiakan kepada Rektor Universitas Pendidikan Ganesha, Dekan Fakultas Hukum dan Ilmu Sosial, Ketua Jurusan Pendidikan Geografi sekaligus penguji 1, Pembimbing Akademik sekaligus Pembimbing 2, Pembimbing 1, Penguji 2, Staf Dosen Jurusan Pendidikan Geografi, UPT Dinas Pendidikan Provinsi Bali Kabupaten Buleleng, Kesatuan Bangsa dan Politik Kabupaten Buleleng, Kepala SMA/MA se-Kabupaten Buleleng, Guru Geografi SMA/MA se-Kabupaten Buleleng, dan rekan-rekan mahasiswa Jurusan Pendidikan Geografi angkatan 2014.

\section{Daftar Rujukan}

Anas, A. Y., Riana, agus W., \& Apsari, N. C. 2015. "Desa dan Kota dalam Potret Pendidikan". Prosiding-KS Penelitian \& Pengabdian Kepada Masyarakat Volume 2, Nomor 3 (hal. 418- 
422).

Azwar, K., Yusrizal, \& Ar, M. 2015. "Pengaruh Sertifikasi Dan Kinerja Guru Terhadap Peningkatan Hasil Belajar Siswa Di Smp Negeri 2 Banda Aceh". Jurnal Administrasi Pendidikan Pascasarjana Universitas Syiah Kuala 10, Volume 3, Nomor 2, (hal. 138-147).

Badan Pusat Statistik. 2010. Klasifikasi Perkotaan dan Perdesaan di Indonesia. Jakarta.

Finn, J. D., \& Achilles, C. M. 1999. "Tennessee's Class Size Study: Findings, Implications, Misconceptions". Educational Evaluation and Policy Analysis, Volume 21, Nomor 2, (hal. 97-109).

Glass, Gene V \& Mary Lee Smith. 1979. "Meta-Analysis of Research on Class Size and Achievement". Educational Evaluation and Policy Analysis, Volume 1, Nomor 1 (hal. 2-16).

Hapsari, Diasty Widar dkk. 2017. "Pengaruh Kompetensi Guru Terhadap Prestasi Belajar Siswa SMK Negeri 2 Bawang”. e-Proceeding of Management, Volume 4, Nomor 1 (hal. 269-274).

Kementerian Pendidikan dan Kebudayaan Indonesia. 2015. Hasil Ujian Nasional Tahun Pelajaran 2014/2015 Kabupaten Buleleng.

Maryani, E. 2006. "Geografi dalam Perspektif keilmuan dan Pendidikan di Persekolahan". (artikel) dimuat dalam buku Ilmu Pendidikan karangan Mohamad Ali (ed). (hal. 1-39): Bandung.

Miski, Rihatul. 2015. Pengaruh Sarana dan Prasarana terhadap Hasil Belajar Siswa. Universitas Djuanda Bogor, Volume 4 Nomor 2 (hal. 69-73).

Vito, B., Krisnani, H., \& Resnawati, R. 2015. "Kesenjangan Pendidikan Desa dan Kota". Prosiding Penelitian \& Pengabdian Kepada Masyarakat. Volume 2, Nomor 2 (hal. 147-300).

Wahyono, S. B. (2006). "Studi Etnografi untuk Pendidikan Perkotaan dan Pedesaan". Universitas Negeri Yogyakarta, (hal 1-15).

Widyastuti, M., Ss, D. R., \& Suparmini. 2017. "Pemanfaatan Laboratorium Geografi untuk Pembelajaran Geografi SMA (Kasus pada SMA di Kabupaten Bantul - Yogyakarta)". Prosiding Seminar Nasional Pendidikan Geografi FKIP UMP 2017 (hal. 28-41).

Zhang, D., Li, X., \& Xue, J. 2015. "Education Inequality between Rural and Urban Areas of the People's Republic of China, Migrants' Children Education, and Some Implications". Asian Development Review, Volume 32, Nomor 1, (hal 196-224). 